\title{
Experimental program on bone technology of the north of Tierra del Fuego: Contributions to the study of production and use-wear traces
}

\author{
Nélida Pal*, Fernando C. Santiago, Myrian Álvarez, Adriana Lasa \\ CADIC-CONICET, Centro Austral de Investigaciones Científicas, Bernardo Houssay 200, Ushuaia, Provincia de Tierra del Fuego, Antártida e Islas del Atlántico Sur, \\ Argentina
}

\section{A R T I C L E I N F O}

\section{Keywords:}

Bone technology

Tierra del Fuego

Experimental program

Functional analysis

Production traces

Use-wear traces

\begin{abstract}
A B S T R A C T
This paper presents an Experimental Program developed to identify, describe and differentiate the production traces from use-wear traces on bone artifacts, through the application of functional analysis framework. For this purpose, several types of guanaco bone tools present in northern sites of the Isla Grande de Tierra del Fuego (South America) were replicated. The results enable us to: 1) differentiate and define the microscopic traces related to the manufacture techniques implemented in the production sequence: scraping, abrasion and sawing as well as 2) identify and describe the use-wear traces of different resources (wood, hide and bark).

The results have allowed to identify the manufacture traces that were formed in each stage of the production process as well as the use-wear traces of different working procedures. Likewise, the data obtained have enabled us to identify the differences in the use of dry and fresh bones, their effectiveness in different labour processes and their respectively diagnostic traces. Thus, we attained a regional frame of reference to study bone technology carried out by hunter-gatherer societies that occupied the Fuegian steppe during the late Holocene.
\end{abstract}

\section{Introduction}

The exploitation of bones as raw material for tool production has been broadly documented in numerous archaeological contexts worldwide. Hunter-gatherers groups who inhabited the Magellan-Fuegian Archipelago located at the uttermost part of South America, took advantage of bone technology from the Middle Holocene until the arrival of European populations. It is interesting to note that bone tools were used by societies with an intensive use of marine resources and provided with nautical technology as well as by pedestrian groups who developed a variable exploitation of coastal and terrestrial resources. Diverse anatomical units of different species of cetaceans, birds, pinnipeds, camelids and canids were used to make processing and hunting tools and ornaments. According to the available information, several bone tool morphologies show a widespread geographical distribution, while others display more regional specificity. Despite the importance of bone technology in the region, the production process and the context of use of these tools are scarcely known with few exceptions (Scheinsohn, 1993; Scheinsohn, 2010; Álvarez et al., 2014; Christensen, 2016; Christensen and Legoupil, 2016).

The general objective of this paper is to contribute to the study of the modes of production and use of bone technology carried out by the hunter-gatherer societies that occupied the Fuegian steppe during the late Holocene. For that purpose, we developed an experimental program aimed at replicating bone tools found in archaeological sites of the northern area of the Isla Grande de Tierra del Fuego (IGTDF), in order to identify and distinguish the formation processes of technological and use-wear traces. In addition, we attempted to increase the number of experimental studies developed on bone technology, as well as to create a frame of reference to be applied to other archaeological contexts of hunter-gatherer societies.

To accomplish these aims, we specifically focus on six types of artifacts made on long and flat bones of guanaco (Lama guanicoe, Müller, 1776), a large terrestrial camelid that played an outstanding role in pedestrian hunter-gatherers subsistence (Borrero, 1985, 1990; Muñoz, 2002; Muñoz, 2012; Calás, 2009; Santiago y Vázquez, 2012; Santiago, 2013). This assemblage comprises: bone blunted points, bone acute points (awls), bipoints, camelid long edges on scapula, blanks made on diaphysis fragments and beveled edges. Bone blunted points and bone acute points show a wide geographical distribution and were identified in coastal and inland archaeological sites of hunter-gatherer societies who exploited terrestrial and marine resources such as Las Vueltas 1 (949 \pm 41 AP), Margen Sur (838 AP), San Pablo 1 (290 \pm 70$)$ and 7 (s/f), Punta María 2 (300 \pm 100) and 16 (s/f), Marazzi 2 (1600 AP), and Punta Baxa 7 (1210-1820 AP) In contrast, bipoint, camelid long edges on scapula and blanks made on diaphysis fragments without

\footnotetext{
* Corresponding author.

E-mail address: nelidpal@gmail.com (N. Pal).
} 
Camelid fragment diaphysis without shaping (CDWS)
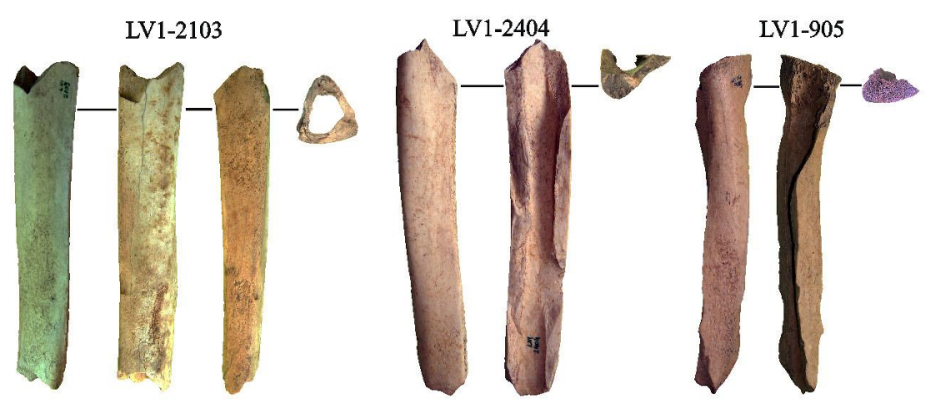

Camelid long edges on scapula (CLES)

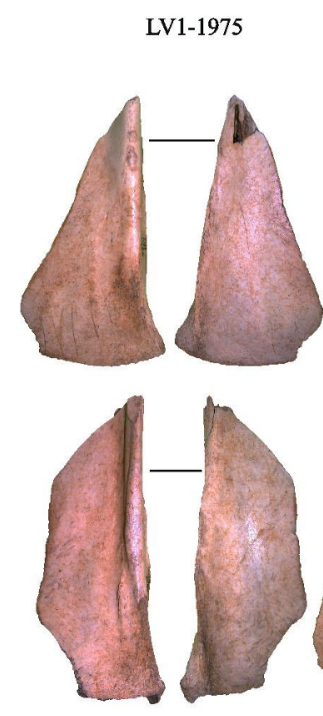

LV1-2621
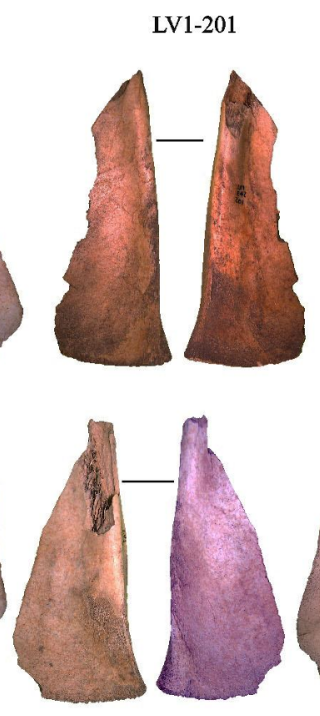

LV1-2463

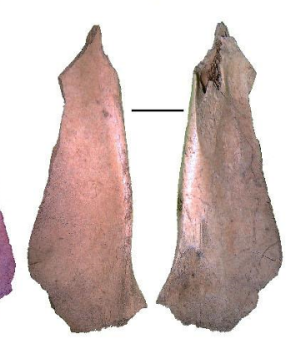

LV1-1835
LV1-410
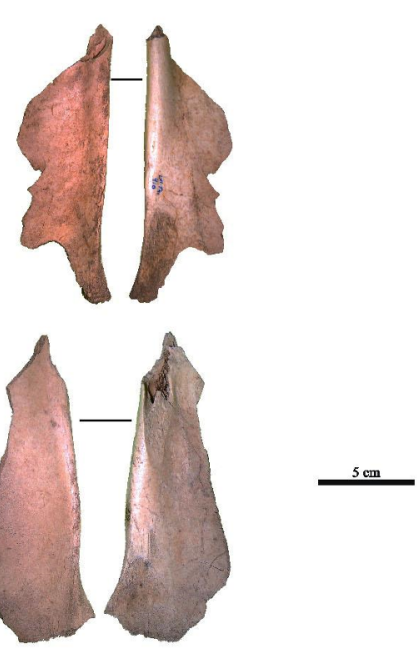

Fig. 1. Bone artifacts recovered at the Las Vueltas 1 site.

Camelid bipoints (CBiP)

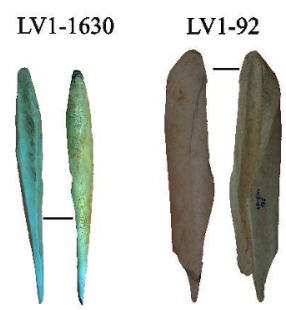

Camelid acute Point (CAP)

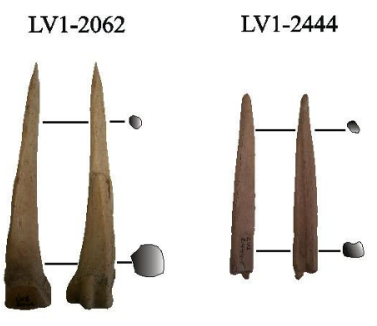

Camelid blunted points (CBP)

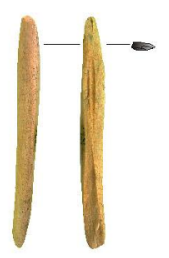

LV1-1961

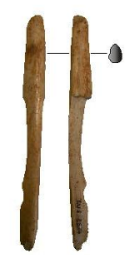

LV1-2358

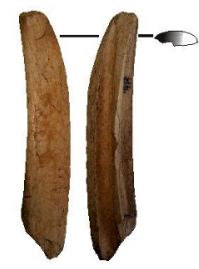

LV1-939 shaping (known in the literature as soft hammers) have only been retrieved at the Las Vueltas 1 site, and the last two artifacts had not been previously identified on the island (Fig. 1). Finally, beveled edge was identified in San Pablo 1 site. All of these sites were dated during Late Late Holocene, last 2000 years (Borrero, 1985; Morello et al., 2004; Morello et al., 2015; Salemme et al., 2019; Santiago et al., 2019a, 2019b, Fig. 2).

\section{Materials and methods}

In recent years there has been a considerable increase in research of bone technology worldwide. These works cover various topics that includes: the identification of the manufacture techniques, the study of the morphological designs, the analysis of the context of use and the study of the regional variability of bone artifacts (Abrams et al., 2014; Alvarez, 2014; Averbouh et al., 2016, 2017; Borao Alvarez et al., 2016; Bradfield, 2015; Buc, 2011; d́Errico et al., 2012; LeMoine, 1994; Santiago et al., 2019; Buc, 2012; Buc et al.,2014; Hutson et al., 2018; Legrand, 2007; LeMoine, 1991; Maigrot, 2003; Santiago et al., 2019a). All of them have made important contributions to the study of innovations, changes and persistence of technological traditions (Legrand and Sidéra, 2007). In the specific case of Tierra del Fuego, the research on bone technology have been undertaken from various approaches and have been mainly focused on the assemblages produced by coastal societies; these approaches have included: 1) the analysis of mechanical properties of bones (Scheinsohn, 2010; Scheinsohn y Ferretti, 1995) and the study of the their metric and morphological structure (Scheinsohn 2010, 2013); 2) the identification of decorative patterns (Fiore, 2011, 2012); 3) the interpretation of use wear traces (Nami and Scheinsohn, 1997; Álvarez et al., 2014; Alvarez Soncini and Léglise 2017) and 4) the production and use of bone assemblage (Nami and Scheinsohn, 1997; Santiago et al., 2019a, 2019b).

Within these lines of research, use-wear analysis has undoubtedly revealed important insights into the study of bone technology to the extent that it allows to identify and to distinguish technical and wear traces. The critical use of historical and ethnographic sources along with the development of an experimental program are key methodological steps to attain a deep comprehension of the formation processes of traces related to the manufacture and use of bone tools; these steps provide a general dataset to build models, to propose hypotheses and to 


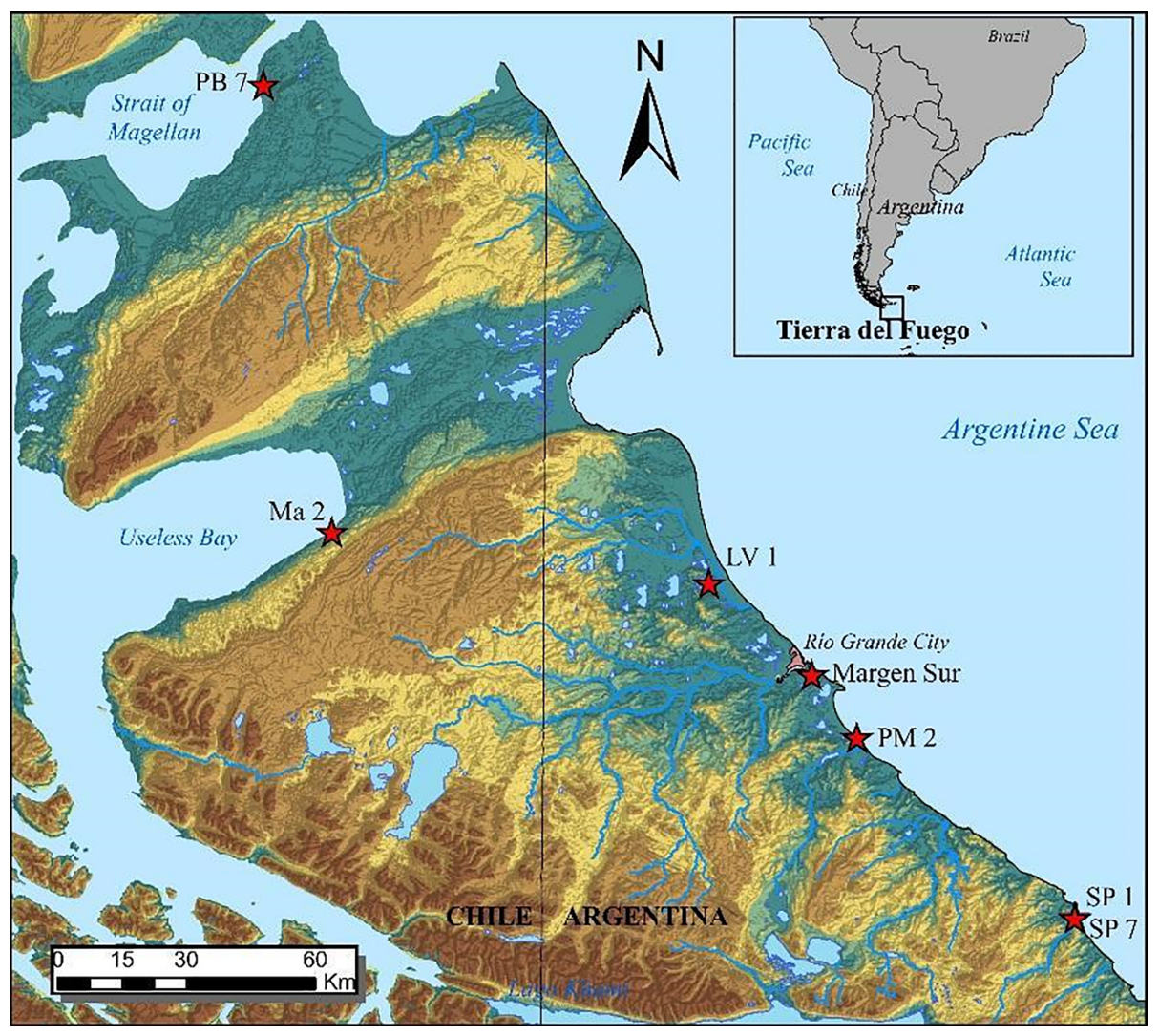

Fig. 2. Archaeological sites with the presence of guanaco bones tools during the late Holocene. Punta Baxa 7 (PB7), Marazzi 2 (MA2), Las Vueltas 1 (LV1), Margen Sur (MS), Punta María 2 (PM2) and San Pablo 1 and 7 (SP1 y SP7) (Borrero, 1985; Morello et al., 2004; Morello et al., 2015; Salemme et al., 2019; Santiago et al., 2019a, 2019b).

make inferences about the context of use of bone tools. Consequently, in the following sections we will present the data obtained from the ethnographic sources and the experimental program addressed to the manufacture and use of bone artifacts.

To identify technological and use-wear traces, we follow the criteria proposed by Semenov (1964), Nami and Scheinsohn (1997), Averbouh (2000), Maigrot (2003), Tejero (2009), Buc (2011), Mallye et al. (2012), Borao Álvarez (2013) and Álvarez et al. (2014). Likewise, according to Scheinsohn's proposal (2010), the definition and description of the artifacts are centered on the morphology of the active part of the tool to avoid functional adscriptions based on untested design features.

Each experimental bone artifact was observed and photographed using a trinocular stereomicroscope Numak Ltz-3 with magnifications between 6 and $60 \times$, provided with a TOUPCAM ${ }^{\mathrm{TM}}$ camera and a reflective light microscope Olympus BHM with magnifications between 50 and $800 \times$ and provided with a PAXcam ${ }^{\mathrm{TM}}$ camera and a specific software PAX-it! to capture and process microscopic images. Both optical instruments have been generally used in different studies (Maigrot, 2003; Christidou and Legrand, 2005; Clemente Conte et al., 2010; Buc, 2011, 2012; Álvarez et al., 2014) because they provide complementary information about technical and functional traces, according to their optical features. The stereomicroscope allows us to identify the active areas of the instruments and to analyze the macroscopic diagnostic traces such as impact fractures, pits and striations. The metallographic microscope enables to study in detail the micropolish topography and brightness and to observe the specific features such as striations, grooves and pits.

\subsection{Ethnographic information}

To accomplish the aims of this study we gathered historical information about two pedestrian societies of IGTDF: the Selknams and the Haushs. The Selknams were hunter-gatherer groups who inhabited the northern portion of IGTDF while Haush people occupied the southeastern part of the island. According to the ethnographic sources (Gallardo, 1910; Gusinde, 1982 [1931]; Lothrop, 1928), both of them made use of bones as raw material to manufacture a broad assemblage of tools such as: acute and blunted points, wedges and harpoons; only acute and blunted points were identified in the archaeological record. The descriptions and data afforded by these accounts allow to generate a frame of reference or hypothesis about manufacture sequences and the mode of use of bone tools.

For example, the ethnographic data reveal that guanaco fibula was used to produce camelid blunted points (flaker); the fibula was fractured or cut, preserving the thickest part of the bone: around one third of the complete element. The broken extreme was transformed into a blunt point by abrasion with a sandstone. These points were used to retouch lithic artifacts (Gallardo, 1910; Gusinde, 1982 [1931]; Lothrop, 1928).

Bird and guanaco bones were also used to manufacture sharp points by sharpening and polishing the distal portion. The ethnographic literature documents two kinds of points: hollow awls and solid points. The hollow awls, made on bird bones, were used by women in bakestry to wave rushes. Contrastingly, solid sharpen points, made on guanaco bones, were employed to pierce hide (Gusinde, 1982 [1931]). Finally, Gallardo reported the use of wedges to break wood to make bows and the beveled edges to split wood (Gallardo, 1910: 259). It is interesting 


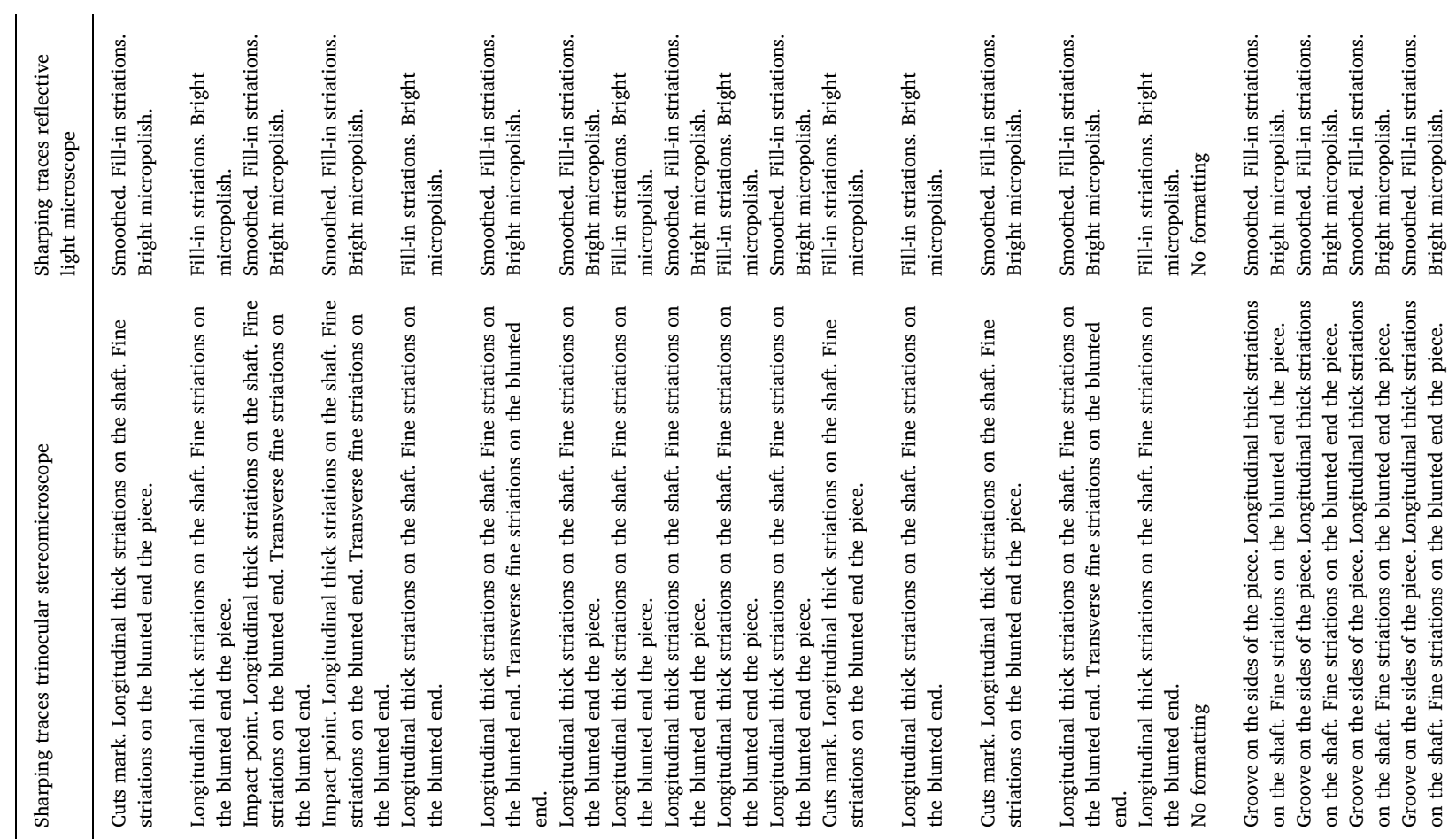

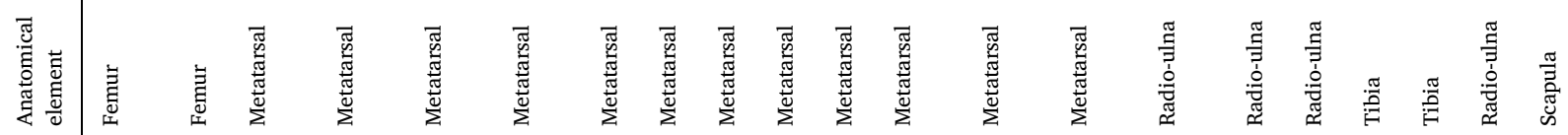

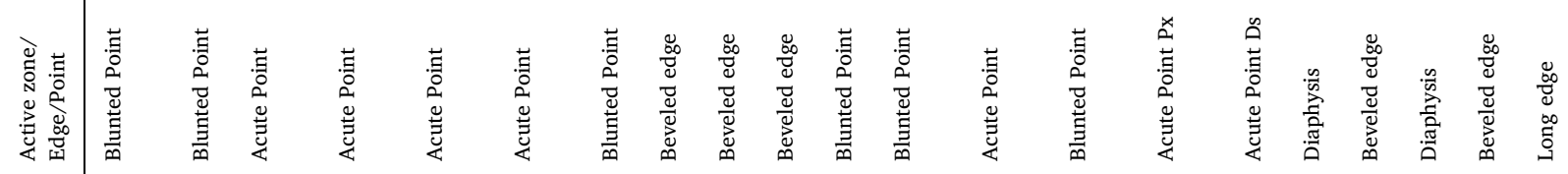




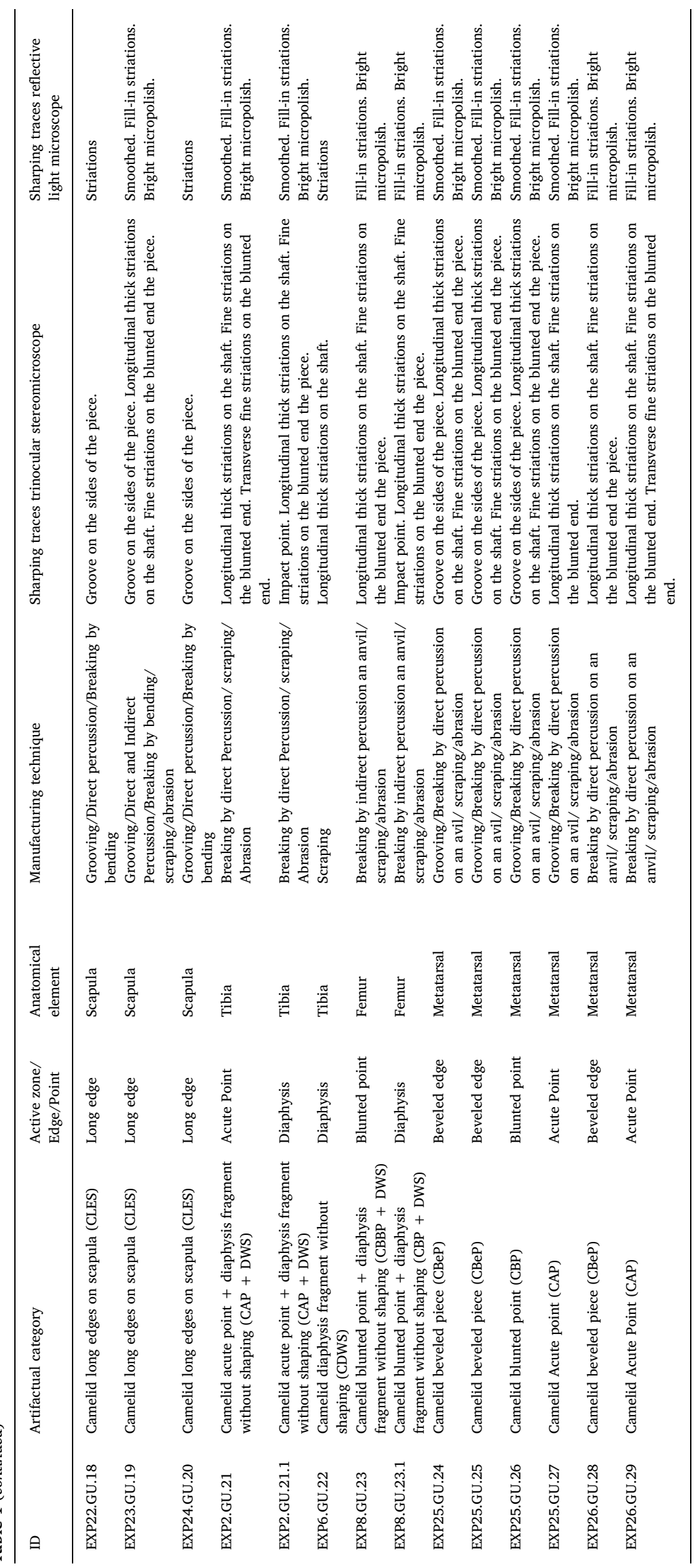


Camelid fragment diaphysis without shaping (CDWS)
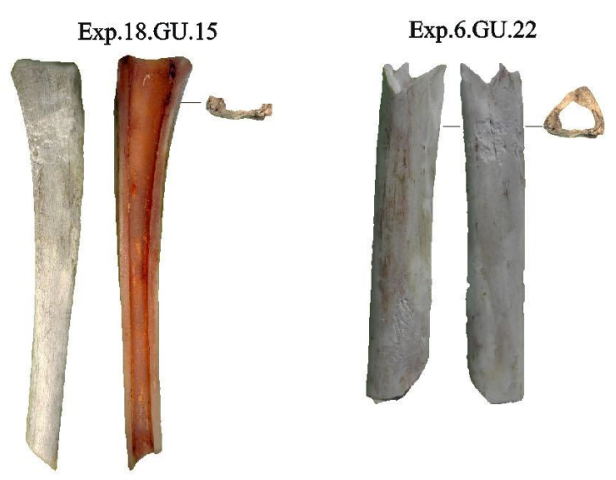

Camelid long edges on scapula (CLES)

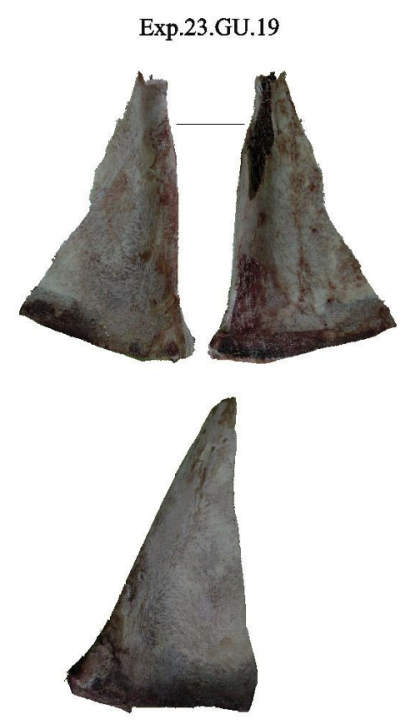

Exp.21.GU.17
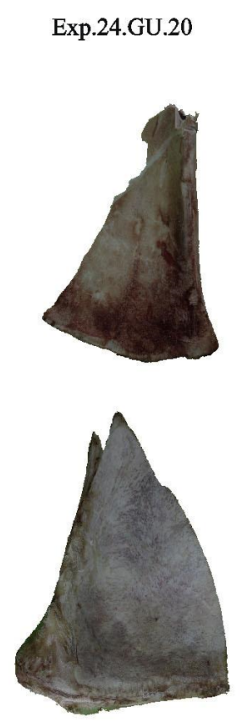

Exp.22.GU.18
Camelid blunted point (CBP)

Exp.10.GU.12 Exp.26.GU.28
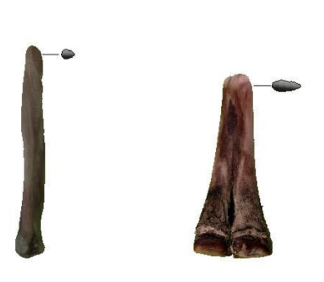

Camelid bipoint (CBiP)

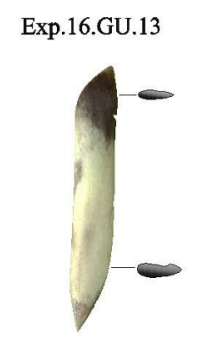

Camelid acute Point (CAP)

EXP.25.GU.27 EXP.26.GU.29
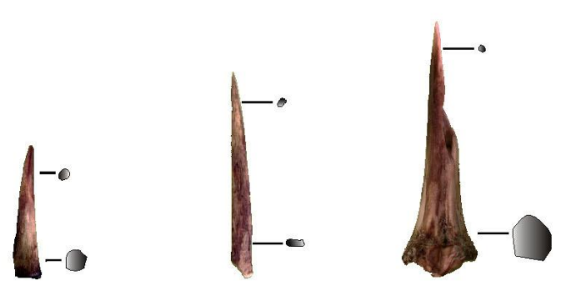

Camelid Bevelled pieces (CBeP)
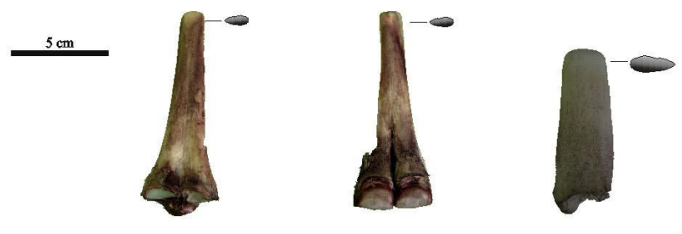

Exp.25.GU.24

Exp.25.GU.25

Exp.20.GU.16

Fig. 3. Examples of experimental bone artifacts. From left to right: camelid diaphysis without shaping (CDWS), camelid blunted points (CBP), camelid bipoints (CBiP), camelid long edges on scapula (CLES), camelid acute points (CAP) and camelid beveled pieces (CBeP).

to note that bipoints, diaphysis without shaping and camelid long edges on scapula are not mentioned in the available ethnographic sources.

The aforementioned data provide information about actions, techniques and gestures performed by past societies. A research strategy that applies the complementary use of ethnohistoric sources and archaeological information is a fundamental step to reproduce the experimental set.

\subsection{The experimental program}

The specific control of variables provides important insights for recognizing and understanding the production techniques and the actions performed by bone tools such as: artifact shaping, worked materials, motion, bone state and activity duration. For this study, six morphotechnical groups were replicated: acute points (awls), blunted points, bipoint, beveled pieces, long edges on camelid scapula and camelid diaphysis without shaping. Currently the sample is formed by 29 artifacts with 37 active zones (Table 1, Fig. 3). For manufacture procedures, fresh bones were selected. Nevertheless, in the case of camelid diaphysis without shaping, we used fresh and dry bones to identify differences and similarities in the process of formation of knapping traces.

The experimental program was designed to undertake sequential activities which include: a) raw material procurement; b) tool manufacture; and c) tool usage (Fig. 4). After the performance of each stage macroscopic and microscopic traces were observed and recorded in order to assess their formation processes as well as to identify their diagnostic features.

\subsubsection{Tool manufacture}

I) Raw material procurement: To manufacture bone tool replicas we selected 2 ulna-radius, 4 metapodial, 1 femur, 3 tibia and 4 scapula from guanaco. Each primary block (or anatomical unit) was fully used for support procurement. For example, 4 different bone tools were made using only one metapodium (see Table 1). The selected blanks required minimal conditioning for the manufacture of tools (See 


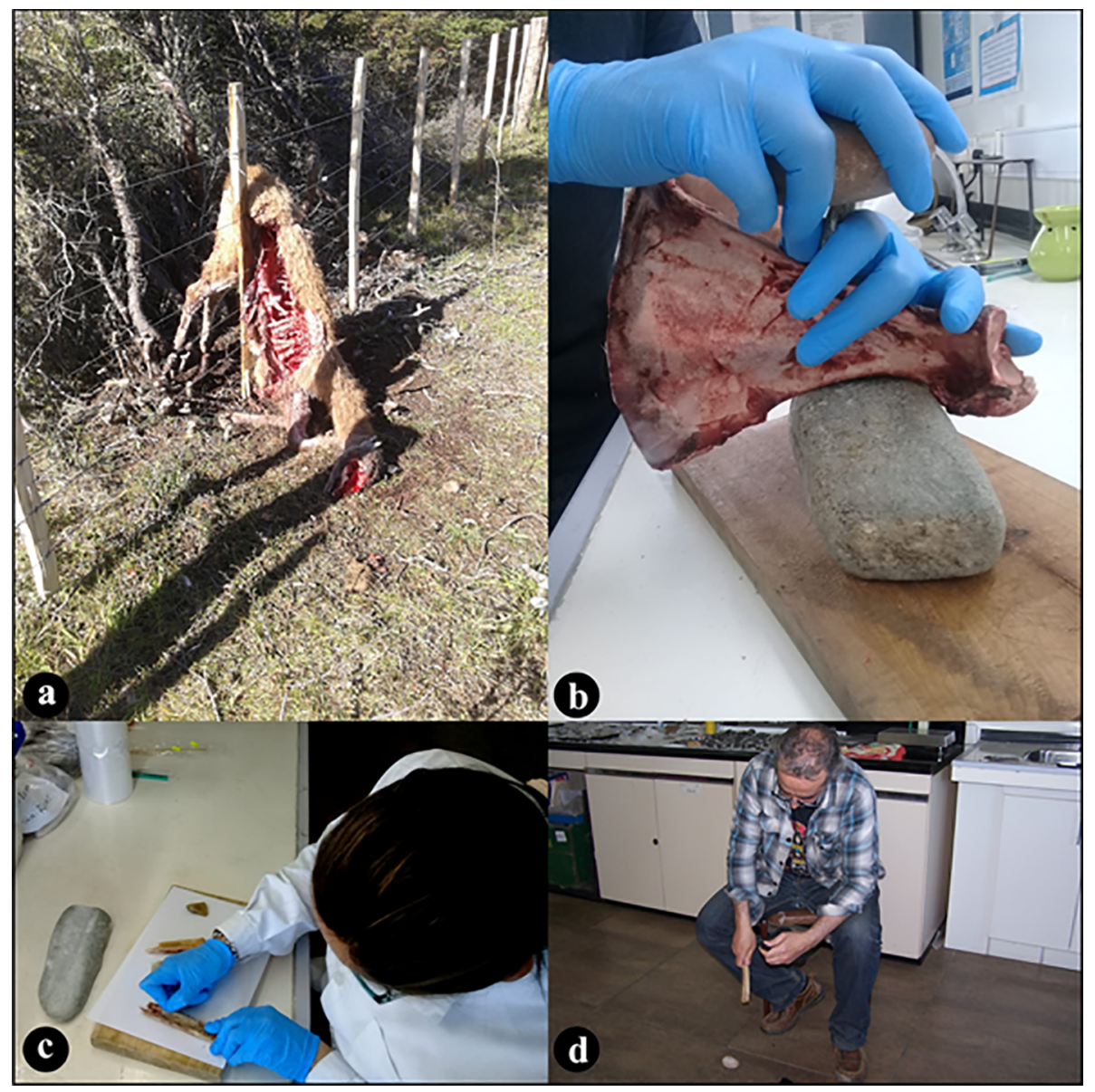

Fig. 4. Different stages of the experimental program: a) Procurement of guanaco carcasses b) Methods of debitage by sectioning, c) Bone instrument replication, d) Use of camelid diaphysis without shaping (CDWS) as soft hammers.

manufacture techniques).

II) Manufacture techniques: According to artifact morphology, different manufactures techniques were applied along the production sequence to obtain bone tools analogues. In order to analyse these techniques, we followed the criteria of Averbouh (2000), Tejero (2009) and Borao Álvarez (2013). Lithic tools were used for the manufacture of bone artifacts. Thus, for direct percussion we employed a cobble and for scraping, sawing and indirect percussion actions, we used rhyolite flakes.

\section{a) Blank procurement}

The activities performed to blank obtention included direct and indirect percussion on anvil, longitudinal grooving and bending (See Table 1 for details). During direct percussion the block was knapped by a stone hammer while in indirect percussion the block was placed on an anvil and a lithic flake, employed as a punch, was struck with a stone hammer; this last technique allowed the force to be directed very precisely. Likewise, the scapulas were previously marked by sawing with a lithic artifact in order to create a groove that facilitates the breakage. Then, the block was broken by direct and indirect percussion and finally, applying progressive force, we bent the bones until they fractured (Fig. 5a).

In the case of ulnas, a groove along the bone was produced, making successive incisions with a lithic artifact. We attempted to split the primary blocks by indirect percussion using a flake in the groove as a punch. However, this technique was not successful to accomplish our aims.

The aforementioned techniques are difficult to identify when the tool is completely shaped since the production stages remove or mask technological traces related to the first activities of "chain opèratoire". However, sawing marks and percussion points have been microscopically observed in the experimental collection.

\section{b) Blank shaping techniques}

Blank shaping included different actions. For example, we made parallel incisions on the blank edge to remove and to regularize the bone surface. Scraping was also performed following the major axis of the piece using the natural edge of a lithic artifact; this technique not only allowed to remove matter from a surface, but also to regularize or to thin out bone surfaces, creating a set of grouped grooves. Abrasion technique was applied on active zones of artifacts and involved rubbing away the bone surface using a sandstone in order to shape the blank that loses fine particles. For example, to edge shaping we made transversal cutting to remove protuberances, then we scraped the surface to remove periosteum and to regularise the surface, finally abrasion was performed to shape the edge. Shaping distal or proximal sections of 


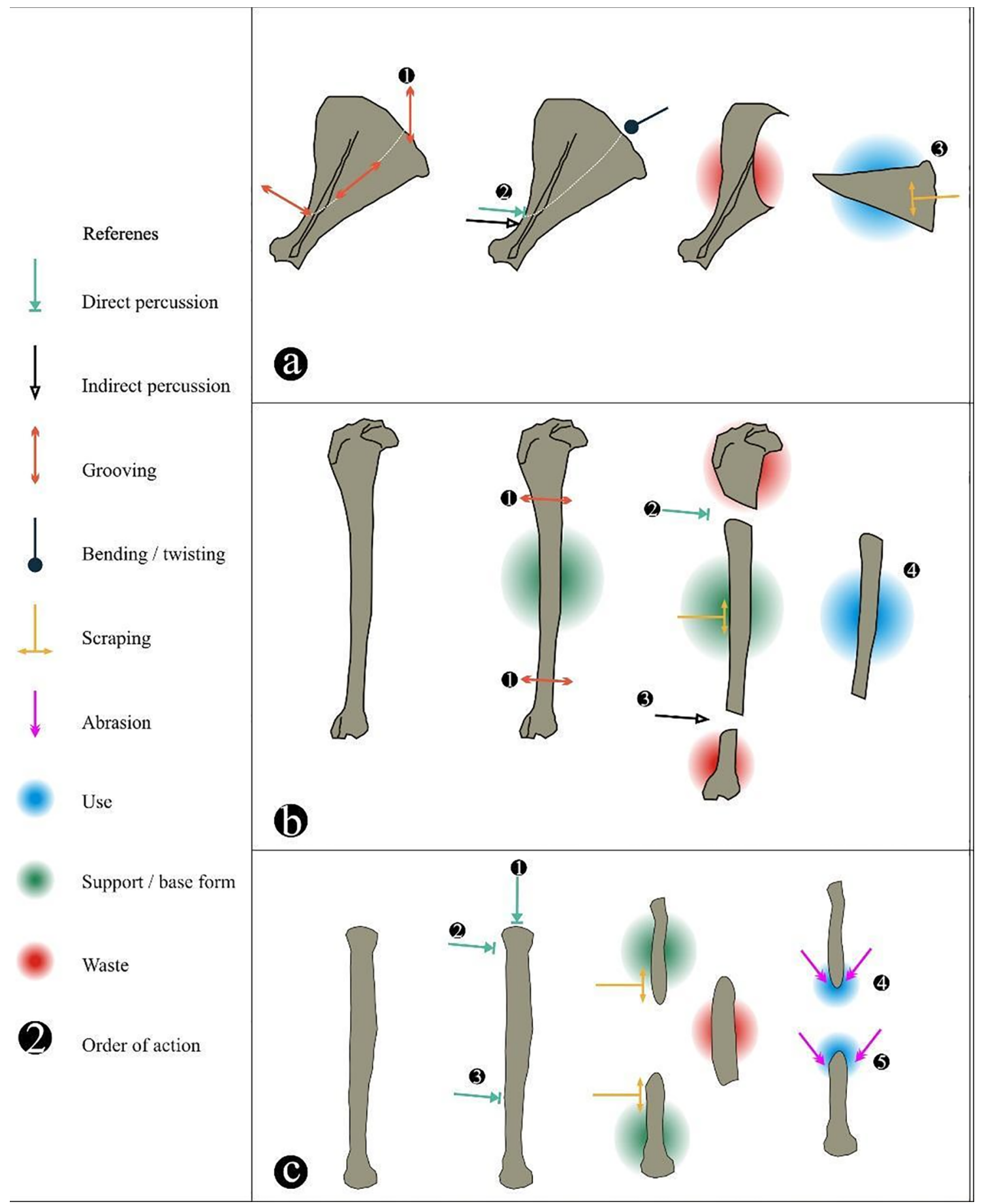

Fig. 5. a) Production of Camelid long edges on scapula (CLES), b) Blank production on Camelid fragment diaphysis without shaping (CDWS, used as soft hammer); c) Production of blunted (CBP) and acute points on Camelid metapodium (CAP).

sharp points was also attained by scraping and abrasion; in contrast, in the case of diaphysis without sharping, only surface cleaning was done with a scraping action using a flake to remove soft tissues (Fig. 5b).

With the aim to reach the final design we polished bone surfaces. This technique implies to rub the surface with a fine-grain rock; in this case we use a slate. This process produces removal and displacement of matter which is re-organised in an interface between the contact area of the working tool and the surface of the worked material (Álvarez et al., 2014). The mechanisms of polish formation follow the same pattern as the mechanisms of microwear polish produced by utilization of the lithic tools (see Use-wear traces: Micropolishes and striations). All the experimental artifacts shaped by abrasion showed a bright smooth surface with through-shaped striations with a grooved bottom (Fig. 3c). 
Table 2

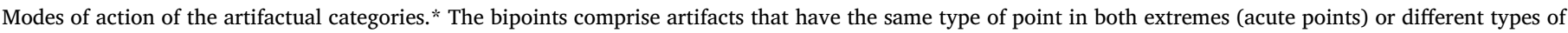
points (blunted point in one extreme and acute point in the other).

\begin{tabular}{|c|c|c|}
\hline Modes of action & Typological group & Functional hypothesis \\
\hline Piercing and weaving & CAP (Camelid acute Point) & Awls: Piercing hide and bark; weaving of baskets (Gusinde, 1982 [1931]; Gallardo, 1910). \\
\hline Lever action & CBeP (Camelid Bevelled pieces) & Removing bark from Nothofagus (Lothrop, 1928). \\
\hline Pressure & CBP (Camelid blunted point) & Flakers or Retouchers. Retouch lithic artifacts (Gusinde, 1982 [1931]; Lothrop, 1928; Gallardo, 1910). \\
\hline Scraping and cutting & CLES (Camelid long edges on scapula) & Wood and soft vegetables working (Santiago et al., 2019a). \\
\hline Percussion & $\begin{array}{l}\text { CDWS (Camelid fragment diaphysis without } \\
\text { shaping) }\end{array}$ & Soft hammer (Mallye et al., 2012; Mozota, 2017). \\
\hline Piercing/Pressure & CBiP (Camelid bipoint)* & $\begin{array}{l}\text { Piercing hide and bark; (Gusinde, } 1982 \text { [1931]; Gallardo, 1910). Retouch lithic artifacts (Gusinde, } 1982 \\
\text { [1931]; Lothrop, 1928; Gallardo, 1910). }\end{array}$ \\
\hline
\end{tabular}

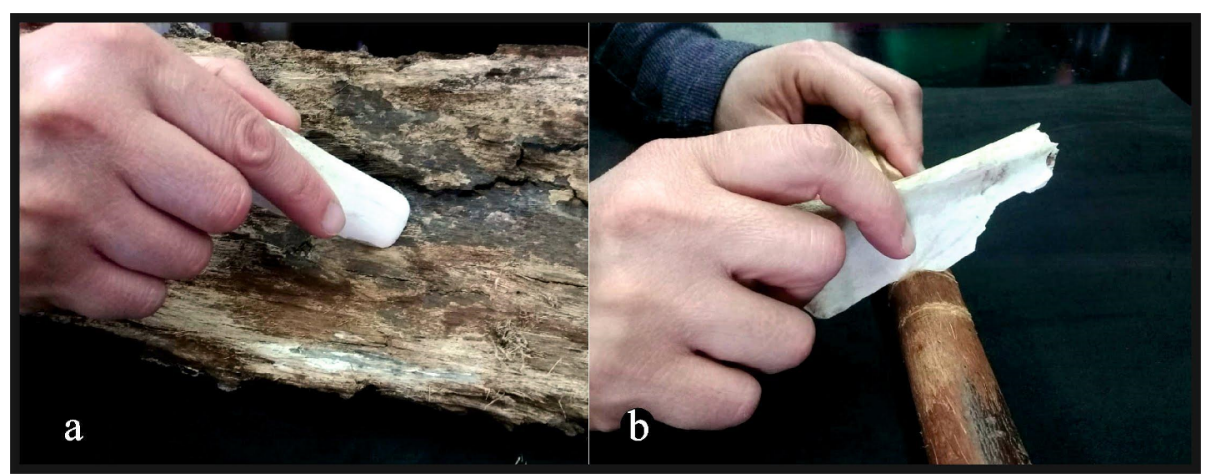

Fig. 6. Experimental activities to produce use-wear tracesa) Bark working, b) Wood working.

\subsubsection{Use of shaped artefacts}

For carrying out use-wear experimental program, we took into account the relation between the modes of use, the morphotechnical groups and the hypothetical function according to the information recorded in the ethnographic sources and previous studies (Scheinsohn, 2010, see Table 2). Thus, the use-wear experimental program developed in this study was oriented and organised based on the work done on the following raw materials: guanaco hide, wood and bark of Nothofagus pumilio (Poepp. et Endl) Krasser. In the case of guanaco hide and N. pumilio bark, drilling and scraping activities were carried out on fresh and dry materials. Scraping and cutting was only performed on fresh Nothofagus wood.

The resources were processed during 30,60 and $90 \mathrm{~min}$ to observe the different formation stages of the use-wear traces (Fig. 6). The diaphysis without technical modifications were used as soft hammers and $30 \mathrm{~S}$ were carried out on flake borders of different raw materials such as glass, rhyolite and silicified rock. The blunted points were used as retouchers by exerting pressure on lithic edges; 30 pressure movements were performed on flakes made on the aforementioned raw materials. Both kinds of instruments were used to regularize flakes borders with the aim to produce long, retouched edges. In Table 3 we specify the controlled variables related to the use-wear experimental program and we describe the traces observed and distinguished under the stereomicroscope and under the reflective light microscope.

Then, the changes on the contact surface of the bone artifacts were observed and use-wear traces of each work were identified (Semenov, 1964; Griffitts, 1997; Le Moine, 1997; Maigrot, 2003; Backwell and d'Errico, 2004; Clemente Conte et al., 2010; Buc, 2011, 2012; Álvarez et al., 2014). Using a trinocular stereomicroscope and a reflective light microscope, we observed and captured digitized images of: a) natural bone surfaces, b) surfaces shaped by scraping, abrasion and polishing and c) changes produced as a result of the working processes (on natural and modified surfaces)

\section{Results observed under a trinocular stereomicroscope and metallographic microscope}

\subsection{Raw materials without modification: Surface description}

The natural surface of a bone looks greasy, bright and irregular (Fig. 7). The observed internal structure consists of concentric layers of mineralized matrix surrounding the central canals -called Haversian canals- connected with the Volkmann's canals. Among the concentric layers, there are some gaps or spaces (lacunae) where osteocytes (mature cells) are located. The combination of the Haversian canals, concentric layers, lacunae, canaliculi and osteocytes constitute an osteon.

\subsection{Technological traces: Manufactures process}

\subsubsection{Blank procurement}

Under the naked eye and the stereomicroscope, direct percussion traces include impact points, sawing and cutting marks (Fig. 8a and b). In the case of grooving, U-shaped striations with a smooth bottom, parallel to the axis of the piece, were observed; these striations formed as a result of applying pressure with bidirectional displacement which generates compression and material crushing on the bottom and the lateral margins of the grooves (Fig. $8 \mathrm{c}$ and d). Finally, grooves produced by incisions made on the edge to regularise the surface disappear with bone shaping (Fig. 8). 


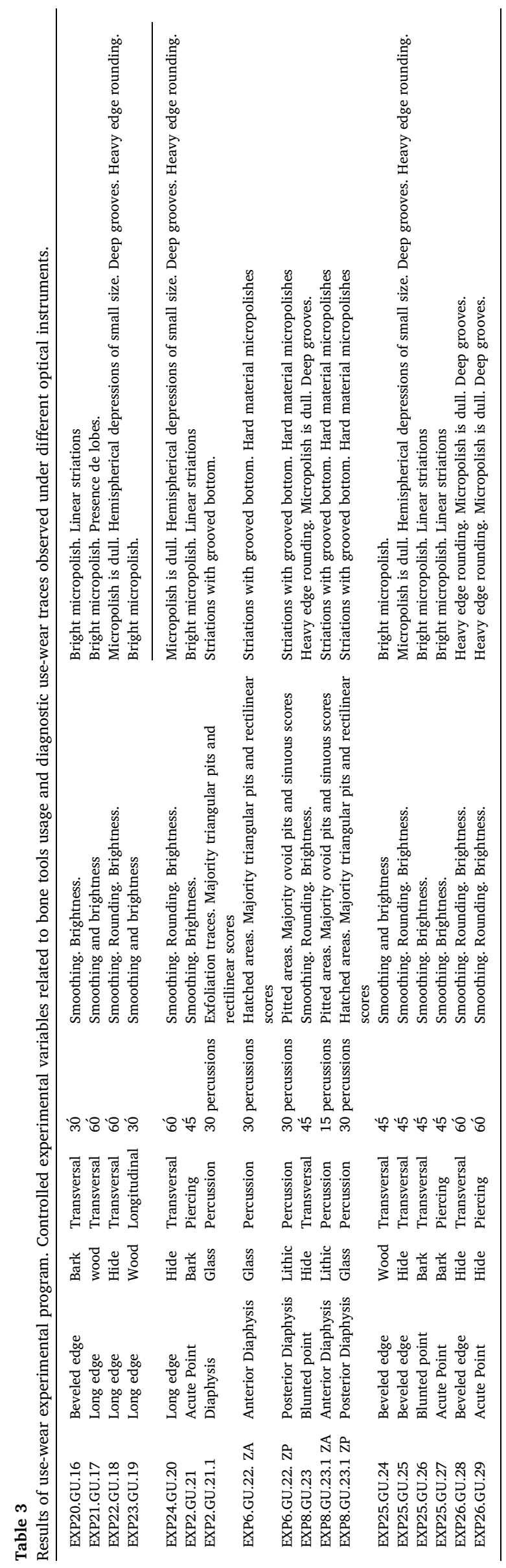

\subsubsection{Blank shaping techniques}

The traces of scraping technique involved surface regularization and striations parallel to each other and located longitudinally to the axis of the piece forming bands. Under the reflective light microscope, we observed fine, dark and linear striations together with micropolishes. The aforementioned traces modify and mask the bone structure at microtopographic level.

Observed with the stereomicroscope, abrasion technique entails the smoothing of bone surface, with striations of different thickness related to the grain size of the abrasive material. In some artifacts, material removal is also observed. The striations are straight, show a rough texture and are grouped in bands; in some cases inclusively, they overlap and intersect, as a result of the repetitive movement, (i.e., they are multidirectional). Likewise, surface rounding is detected, in association with an intense brightness. Under the reflective light microscope, the artifact surface appears smoothed, with fill-in striations and bright micropolish. The original features of the bone are not observed (Fig. 8e-h) (Buc and Loponte, 2007; Álvarez et al., 2014).

\subsection{Use-wear traces: Micropolishes and striations}

Micropolishes imply a general modification of the surface defined by micro-topographic criteria (such as brightness, surface regularity), distribution, extension, the presence of particular features (such as micro-pitting) and the attributes of associated striations (Maigrot, 2003). The formation of micropolishes, in some cases, mask the technical traces produced by the manufacture of the tool, fill in the striations and smoothing the surface, until the technological production traces disappear completely (Álvarez et al., 2014).

Traces are better developed on unmodified natural surfaces. However, it was possible to describe and analyse the traces formed during the manufacturing process of those formed during the working processes, due to the control of the variables taken into account during the experimental program. Nevertheless, in the archaeological artifacts shaped by abrasion/polishing techniques, the distinction between manufacture polish, use-wear polished and shiny areas produced by taphonomic processes, it is not a straightforward task.

\subsubsection{Wood scraping and sawing}

Seven active zones (long edge, acute point and beveled piece) were used to fresh wood working (see Table 3). Under the stereomicroscope a reflective and smooth surface is observed. In the reflective light microscope, micropolish appears bright and domed in the first stage of formation; when it is well-developed it forms lobes continuously distributed over the cutting edge, covering low and high parts of the microtopography. Several thin long striations with smooth bottom are observed indicating tool motion (Fig. 9a). These striations are included in the micropolish layer and are located parallel or transverse to the edge of the piece, according to the movement made by the tool (Cutting or scraping) (Clemente Conte et al., 2010; Álvarez et al., 2014).

\subsubsection{Hide scraping and perforation}

Hide working was carried out on 11 active zones (acute point, beveled piece, blunted point and long edge, see Table 3). In the stereomicroscope a reflective and smooth surface is observed. Under the reflective light microscope fresh hide-working produced heavy edge rounding with the formation of numerous hemispherical depressions of small size and deep grooves that indicate tool motion; the surface looks smooth and bright. The micropolish is dull, thin with greasy appearance (Fig. 9d). The development of this micropolish was slow (60' of work). During the first stages, it was found mainly in the high parts of the edge topography and during an advanced stage, it was located both in high and low parts of the topography (Fig. 9f). Numerous fine, short or long, superficial and continuous striations are observed (Gates St-Pierre, 2007; Legrand, 2007; Legrand and Sidéra, 2007; Clemente Conte et al., 2010; Buc, 2011; Álvarez et al., 2014). 


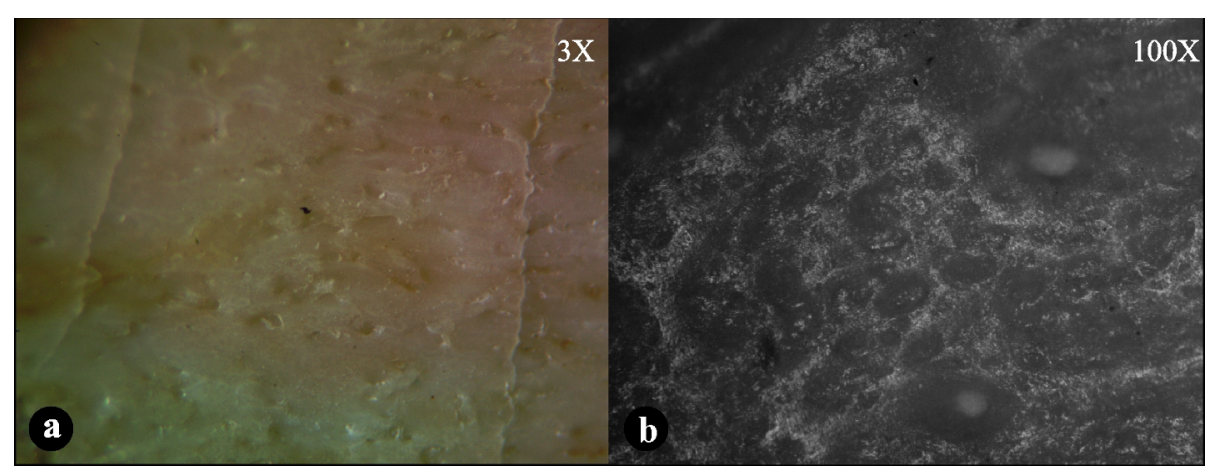

Fig. 7. Manufacture traces on unmodified bone surfaces a) Trinocular stereomicroscope image. Magnification: $3 \times$. b) Reflective light microscope image. Magnification: $100 \times$.

\subsubsection{Cutting and drilling of Nothofagus bark}

For bark working, we used 8 active zones, such as blunted point, acute point and beveled piece (see Table 3). Dry bark working tools, observed under the stereomicroscope show surface regularization, edge rounding and the apices became blunt after $60 \mathrm{~min}$ of use. Linear and long striations with rough bottom distributed obliquely to the edge are also identified (Fig. 9h). As a consequence of the working process manufacture striations are completely eliminated of the contact zone. Under the microscope, a bright micropolish with few linear striations that have a U-shaped bottom are observed (Fig. 9h); these use-wear traces cover and hide manufacture traces (Gates St-Pierre, 2007).

\subsubsection{Percussion on hard material (soft hammers)}

Four diaphysis without technical modifications were employed for percussion (soft hammer): in two cases we used two active zones. The blanks were used in dry $(n=2)$ and fresh state $(n=2)$ in order to compare their performance and to detect probable differences in usewear traces. During the experimentation program, we detect differences between use-wear traces according to the knapped raw material observed with the aid of the stereomicroscope. The percussion on rhyolites ovoid forms deep and short pits, as well as, areas with pits and striations (sensu, Mallye et al., 2012; Hutson et al., 2018). In the case of glass, deep striations with rectilinear morphology are generated, associated with thin striations with smooth inner faces. Both pits and striations are characterized by being isolated, scattered and/or clustered in some pieces, they even constitute small areas where the cortical surface of the bone was detached (see also, Mallye et al., 2012; Mozota, 2012, 2017; Blasco et al., 2013). In the instruments worked by both raw materials, fine and parallel striations were identified, transverse to the axis of the pieces produced by the hammer friction on the lithic edge to improve the extraction of the flakes.

Likewise, we explore the relationship between the traits of the percussion traces and the state (fresh vs. dry) of retoucheŕs raw material. The higher density of fresh bone facilitates the manufacture of the lithic artefact owing to its greater weight. The use-wear traces include pits or striations and depending on raw materials, clustered and overlapping marks of variable depths on well-defined areas (Fig. 10). In the case of the retouchers made on dry bone, the presence of linear striations and pits is recorded, as well as the loss of cortical tissue when glass is knapped. This latest feature was described by Blasco and collaborators (2013) as exfoliation traces similar to weathering processes (Blasco et al., 2013, Fig. 10)

The experimental pieces EXP6.GU.22 and EXP8.GU.23 were used twice as soft hammers. Thus, two areas of use were created on the front and back of the artifacts. Of the four hammers, only EXP8.GU.23 was fractured during the second use (Fig. 10).

With the metallographic microscope, micropolishes are observed and are consistent with hard material working produced by the percussion and sliding of the epiphysis on the percussion platform or on the artifact edge for flake removal (micropolish located perpendicular to the axis of the piece). Moreover, striations with grooved bottom are identified transversal to the axis of the tool, occasioned by the contact with the lithic material. It is important to note that diaphysis without technical modifications used as soft hammers has not been described before for Tierra del Fuego.

\subsubsection{Compression on hard material (compressors)}

Five experimental retouchers were employed to strike on glass, rhyolite and a siliceous rock. An area with pits is identified with the stereomicroscope. The images obtained with the reflective light microscope enable the observation of short and wide deep grooves parallel to each other and transverse to the axis of the piece (Fig. 11) The traces are located mainly at the apex (see also Borella and Buc 2009; Nami and Scheinsohn, 1997).

\section{Final considerations}

The data provided by this experimental research is very useful to make more detailed inferences about the production and use of bone artifacts in archaeological contexts. Moreover, they contribute to unveil the technological knowledge of the pedestrian hunter-gatherer societies which occupied the Fuegian steppe during the Holocene. The implementation and development of the experimental program together with the use-wear method allowed us to recognize the techniques employed during the different shaping stages, as well as, the movements, uses and to distinguish the traces produced by different working processes; according to the results provided by different researchers, it has been proven that each material leaves a differential pattern.

From a methodological point of view, several results have been achieved with this work. it has been possible to distinguish production traces from use-wear traces. At the same time, the traces of different manufacture techniques performed during the production sequence of bone tools have been clearly identified and it has been shown that a few technical steps are required for the manufacture of these bone instruments. Consequently, labor inversion in production is relatively low.

Differences in the formation process of use-wear traces were also detected according to different variables such as: surface condition or bone state. Thus, use-wear traces are more intensively developed on 


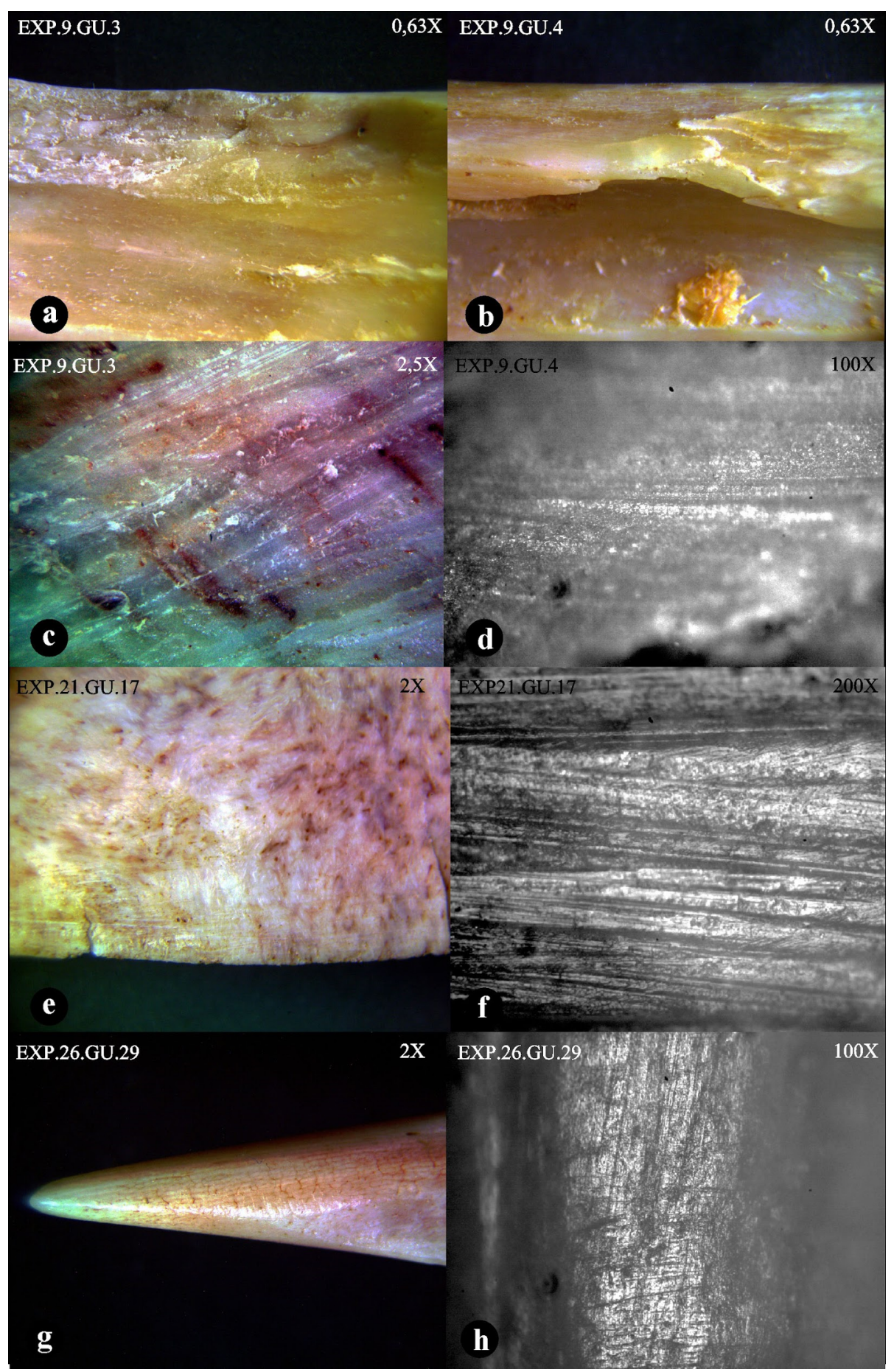

Fig. 8. Manufacture traces. a, b) Techniques for blank procurement: impact point, observed under a stereomicroscope 0,63× (EXP.9.GU.3 and EXP.9.GU.4); c, d) Support shaping techniques: sawing traces under a trinocular stereomicroscope 2,5 $\times$ and a reflective light microscope, 100 $\times$ (EXP.9.GU.3 and EXP.9.GU.4.); e, f) Support shaping techniques: abrasion traces observed under a trinocular stereomicroscope $2 \times$ and a reflective light microscope 200 $\times$ (EXP.21.GU.17) and g, h) Bone artifact finishing technique: Polishing Trinocular stereomicroscope $2 \times$ and Reflective light microscope $100 \times$ (EXP.26.GU.29).

natural surfaces in comparison with shaped tools in which use-wear traces partially or totally overlap and cover production ones; mainly in those areas that were in contact with active borders or points. Likewise, it is interesting to note that dry bones are more fragile and break more easily, due to a decrease in bone collagen content that makes them less flexible and resistant. Therefore it is more effective to use fresh bones for the manufacture and use of bone tools as we have seen in the case of soft hammers or in long edges on guanaco scapulae. 


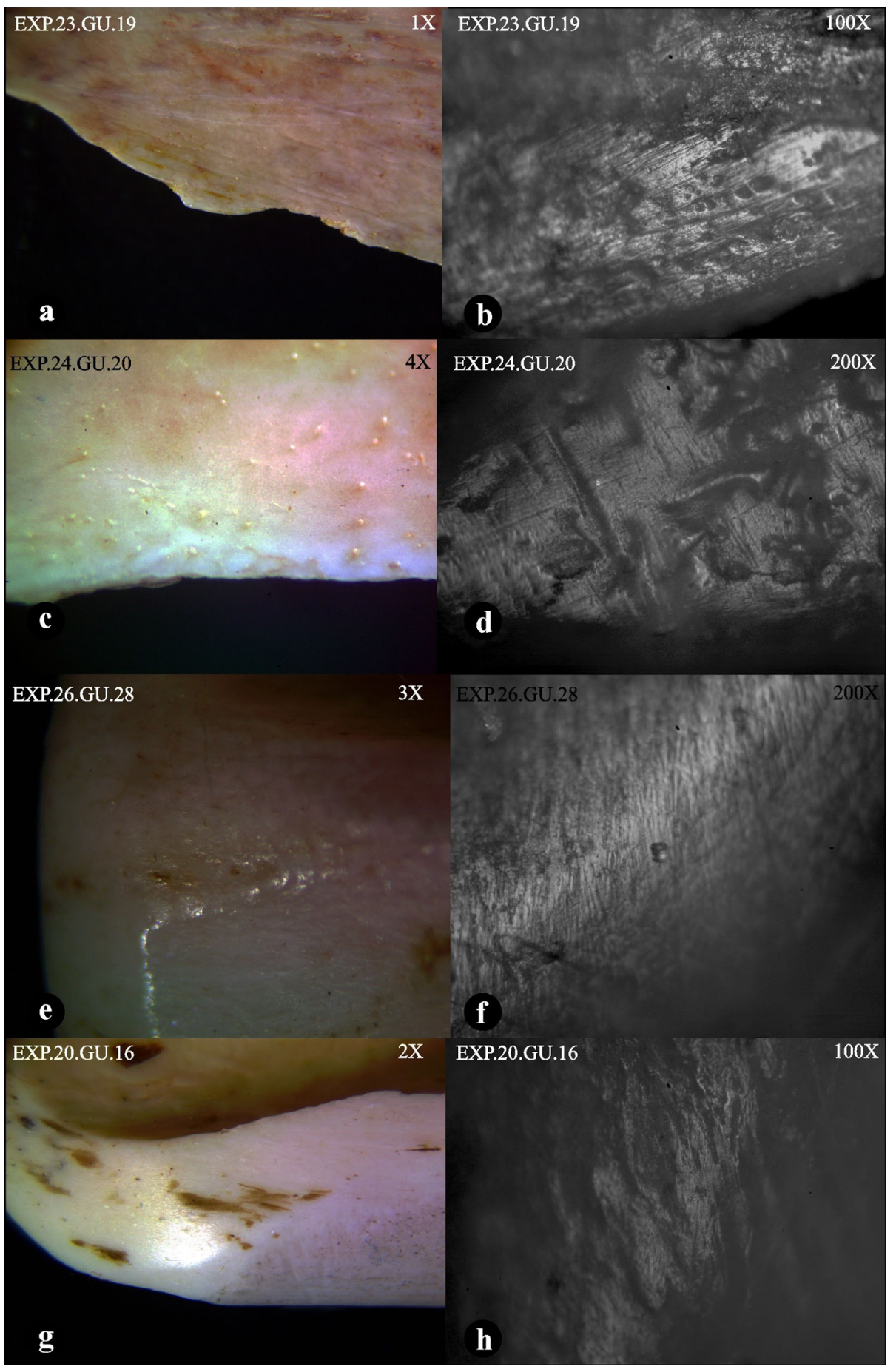

Fig. 9. Use wear traces of: a, b) EXP.23.GU.19. Fresh wood cutting during $30 \mathrm{~min}$ (EXP.23.GU.19). a) Smooth surface and fine striation of blank shaping techniques observed under a trinocular stereomicroscope at $1 \times$ and b) Bright micropolish and striations observed with a reflective light microscope at $100 \times$; c, d). Fresh hide scraping during 60 min (EXP.24.GU.20). c) Smooth surface observed under a trinocular stereomicroscope at $4 \times$ and d) Dull micropolish, hemispherical depressions, deep grooves and fine striation observed under a reflective light microscope at $200 \times$; e, f) Fresh hide scraping during $60 \mathrm{~min}$, (EXP.26.GU.28). e) Smooth and bright surface and edge rounding observed under a trinocular stereomicroscope at $3 \times$ ) and $f$ ) Dull micropolish with fine striations observed under a Reflective light microscope at $200 \times$; g, h) Dry bark scraping during $30 \mathrm{~min}$ (EXP.20.GU.16). g) Smooth surface observed under a trinocular stereomicroscope at $2 \times$ and h) Bright micropolish and linear striations under a reflective light microscope at $100 \times$.

Finally, the archaeological research in Tierra del Fuego has broadly shown that guanacos were an important food source for the huntergatherer groups that occupied the steppe (Borrero, 1990; Muñoz, 2002; Muñoz, 2012; Calás, 2009; Santiago y Vázquez, 2012; Santiago, 2013). The use of different bone elements of this camelid species for the production of different tools such as acute points, blunt tips, bevels, long edges and soft hammers, indicate that not only their meat and fat were valuable source of food, but they were also a significant technological resource, as it has been shown by the experimental and archaeological evidence. Future research including new bone tool morphologies will allow us to gain knowledge about the formation processes of production and use-wear traces. Thus, from a geographical perspective the existence of shared knowledge regional traditions can be disentangled as well as the trends and innovations that occurred along the Holocene. 


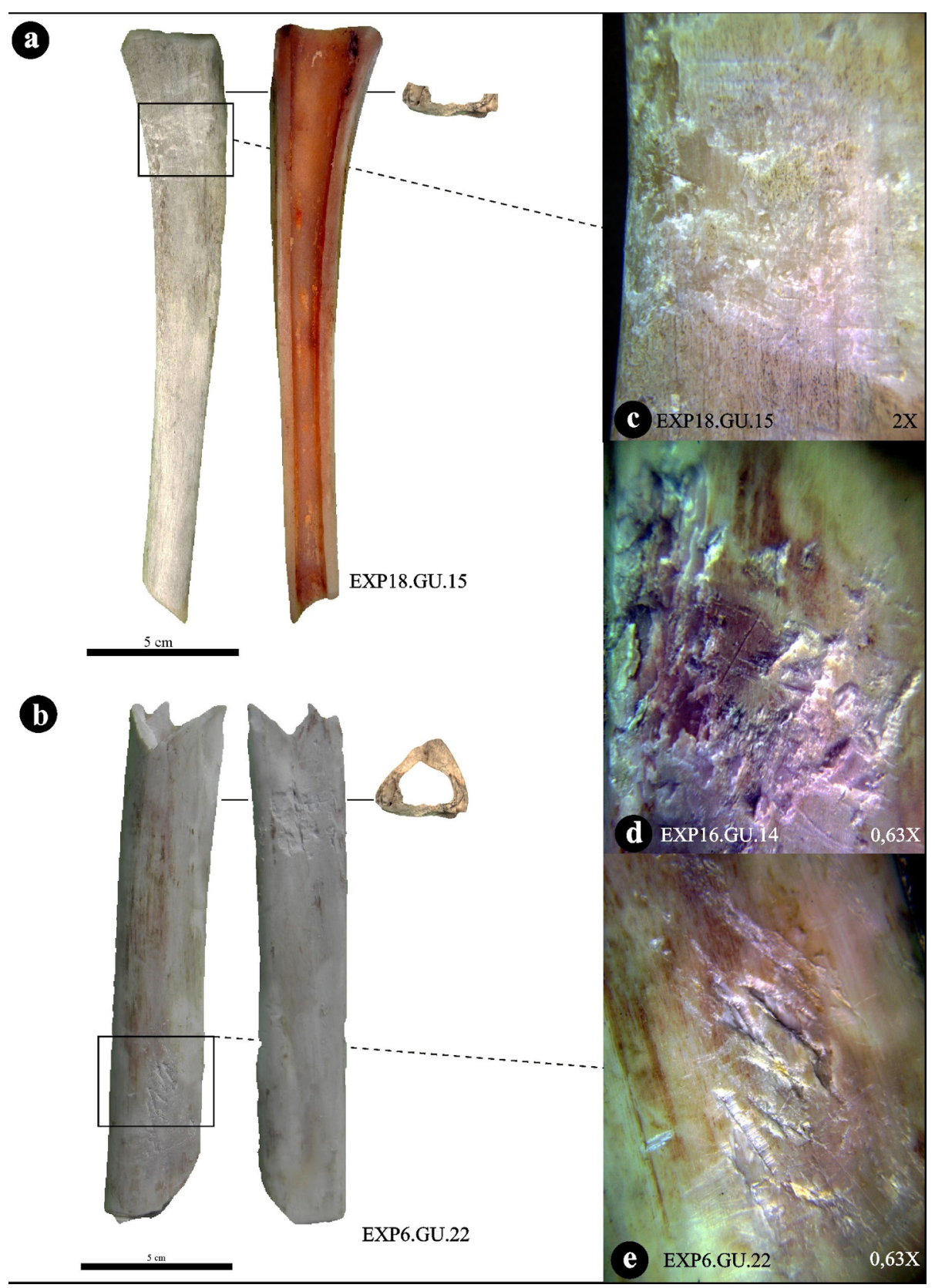

Fig. 10. a) CDWS or soft hammer made on dry bone. b) CDWS or soft hammer made on fresh bone, two zones were used. c) Detail of the used zone of the EXP.18.GU.15 used to work glass, see the exfoliation traces, rectilinear pits and striations, d) Soft hammer made from fresh bone used to work rhyolite, detail of cortical surface of the bone detached, ovoid forms deep and short pits and striations, e) EXP.6.GU.22 Soft hammer made of fresh bone to work glass, detail of striations and pits with rectilinear morphology.

\section{CRediT authorship contribution statement}

Nélida Pal: Conceptualization, Formal analysis, Data curation, Methodology, Writing, review \& editing. Fernando C. Santiago: Writing, review, editing and Funding acquisition. Myrian Álvarez: Writing - review \& editing, Methodology, Funding acquisition. Adriana Lasa: Resources.

\section{Acknowledgements}

This research was funded by Consejo Nacional de Investigaciones Científicas y Técnicas PIP-CONICET 0302/12 (F.S.) and 2017-0348 (M.A.). We are grateful to Martín Vázquez for his help in knapping activities with soft hammers and Valeria Bártoli for her assistance in laboratory tasks. We thank CADIC-CONICET for research facilities. The valuable comments of two anonymous reviewers have allowed us to improve our paper. 


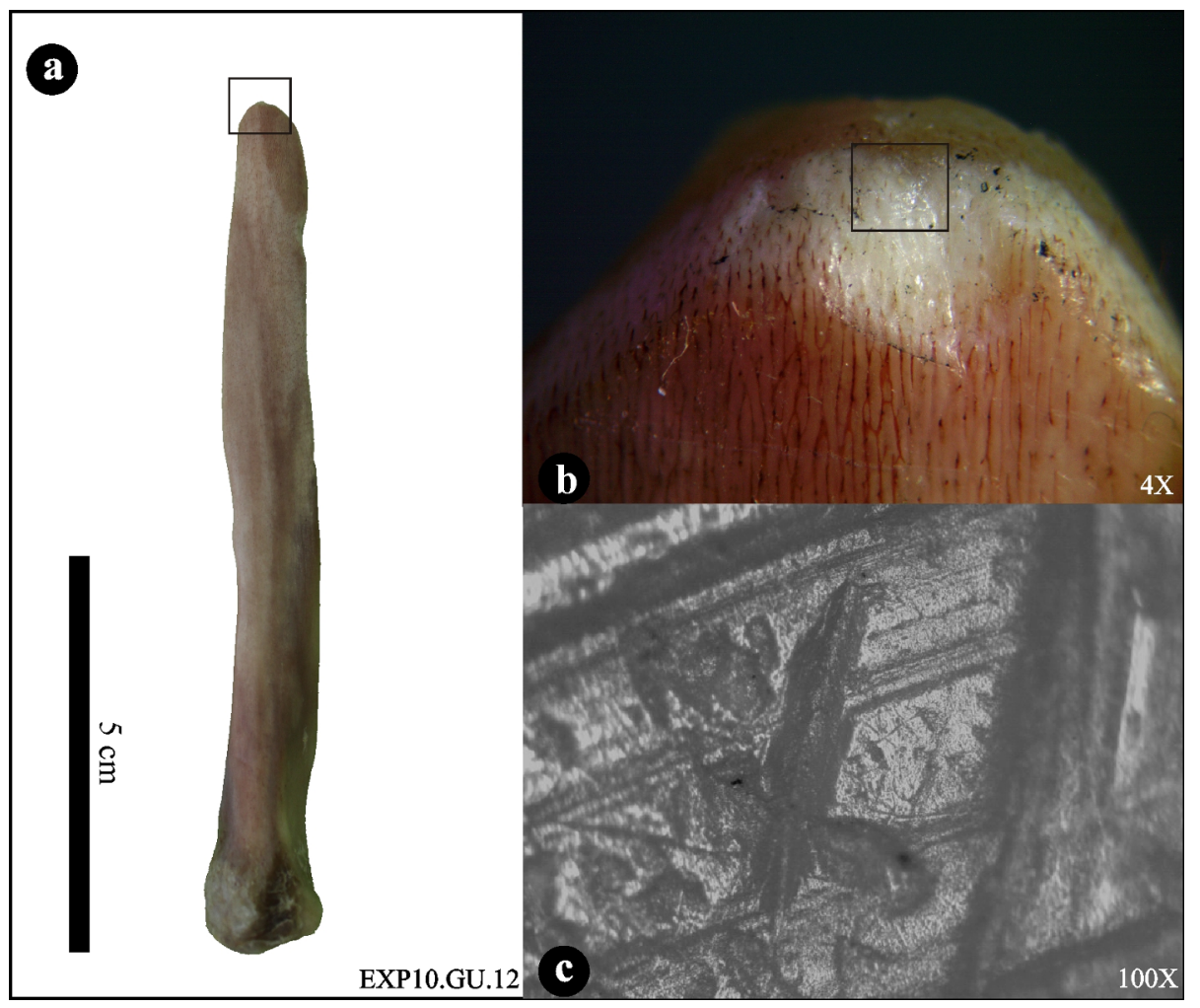

Fig. 11. a) Camelid blunted point or flaker used to exert compression on a natural edge of rhyolite flake (CBP). b) Use-wear traces: pitting (trinocular stereomicroscope image at $4 \times$ ), c) Use-wear traces characterized by short and wide striations above manufacturing traces defined by polished and striations with a grooved bottom (reflective light microscope image at $100 \times$ ).

\section{References}

Abrams, G., Bello, S., Di Modica, K., Pirson, S., Bonjean, Dominique, 2014. When Neanderthals used cave bear (Ursus spelaeus) remains: bone retouchers from unit 5 of Scladina Cave (Belgium). Quat. Int. 326-327, 274-287.

Alvarez, M.C., 2014. Tecnología ósea en el oeste de la región pampeana: Identificación de las técnicas de manufactura a partir de evidencias arqueológicas y experimentales. Chungará 46 (2), 193-210.

Álvarez, M., Mansur, E., Pal, N., 2014. Experiments in bone technology: a methodological approach to functional analysis on bone tools. In: Mansur, E., Alonso Lima, M., Maigrot, Y. (Eds.), Traceology Today. Methodological Issues in the Old World and the Americas. BAR International Series 2643. Archaeopress, Oxford, pp. 19-26.

Alvarez Soncini, C., Léglise, S., 2017. Experimentación tecnofuncional con pulidores líticos y punzones óseos. BAEX: Boletín de Arqueología Experimental 12, 155-184.

Averbouh, A., 2000. Technologie de la matière osseuse travaillée et implications palethnologiques: l'exemple des chaînes d'exploitation du bois de cervidé chez les Magdaléniens des Pyrénées. Doctoral dissertation, Paris 1.

Averbouh, A., Goutas, N., Marquebielle, B., 2016. Rod debitage by extraction: an overview of different cases identified for the Upper Palaeolithic and the Mesolithic in Europe. Quat. Int. 403, 57-67.

Averbouh, A., Tejero, J.M., Goutas, N., Christensen, M., 2017. Innovation in the production and use of equipment in hard animal materials: origins and consequences in prehistoric societies, from the Palaeolithic to the Mesolithic. Quat. Int. 438, 11-14.

Backwell, L., d'Errico, F., 2004. The first use of bone tools: a reappraisal of the evidence from Olduvai Gorge, Tanzania. Palaeontologia africana 40, 95-158.

Blasco, R., Rosell, J., Cuartero, F., Fernandez Peris, J., Gopher, A., Barkai, R., 2013. Using bones to shape stones: MIS 9 bone retouchers at both edges of the Mediterranean sea. PLOS ONE 8 (10), e76780.

Borao Álvarez, 2013. Estudio tecnológico de los útiles fabricados sobre asta y hueso en el Magdaleniense Superior de la Cova de les Cendres (Teulada-Moraira, Alicante). SAGVNTVM. Papeles del Laboratorio de Arqueología de Valencia 44.

Borao Alvarez, M., Villaverde Bonilla, V., Aura Tortosa, J.E., 2016. Debitage by fracturing in the osseous industry of Cova del Parpallo (Gandía-Valencia, Spain): a preliminary study. Quat. Int. 403, 118-131.

Borella, F., Buc, N., 2009. Ópticas y ópticos. Una aproximación a la tecnología ósea en la Bahía de San Antonio (Río Negro), Argentina, in Salemme, M, Santiago, F., Alvarez M., Piana, E., Vázquez, M., Mansur, E. (comp), Arqueología de Patagonia: Una mirada desde el último confín. Utopías, Ushuaia, pp. 421-432.

Borrero, L., 1985. La economía prehistórica de los habitantes del norte de la Isla Grande de Tierra del Fuego. Doctoral dissertation. Facultad de Filosofía y Letras, Universidad de Buenos Aires. Buenos Aires.

Borrero, L.A., 1990. Fuego Patagonia bone assemblage and the problem of communal guanaco hunting. En: Hunter of the recent past, editado por: Davis, L. B. y B. Reeves, pp: 373-339. Unwin Hyman.
Bradfield, J., 2015. Pointed bone tool technology in southern Africa: results of use-trace analyses. Southern African Human. 27, 1-27.

Buc, N., 2011. Experimental series and use-wear in bone tools. J. Archaeol. Sci. 38, $546-557$.

Buc, N., 2012. Tecnología ósea de cazadores-recolectores del humedal del Paraná inferior. Bajíos Ribereños meridionales. D. Loponte \& A. Acosta (Eds.) Arqueología de la Cuenca del Plata. Series Monográfica III. Instituto Nacional de Antropología y Pensamiento Latinoamericano, Buenos Aires.

Buc, N., Loponte, D., 2007. Bone Tool Types and Microwear Patterns: Some Examples from the Pampa Region, South America. In: Gates St-Pierre, C., Walker, R. (Eds.), Bones as Tools: Current Methods and Interpretations in Worked Bone Studies, BAR International Series 1622, pp. 143-157.

Buc, N., Acosta, A., Mucciolo, L., 2014. Blank extraction techniques in bone technology: Hunter-Gatherers from low Paraná Wetland (Argentina). P@lethnologie [En ligne], Contributions, mis en ligne le 28 janvier 2014, consulté le 24 novembre 2019. URL: http://journals.openedition.org/palethnologie/568; doi: 10.4000/palethnologie. 568.

Calás, E., 2009. La subsistencia de los cazadores-recolectores terrestres del Holoceno Medio y Tardío en el norte de Tierra del Fuego. Facultad de Ciencias Sociales. Departamento de Antropología. Universidad de Chile, pp. 202.

Christensen M., 2016. La industria ósea de los cazadores-recolectores: el caso de los nómadas marinos de Patagonia y Tierra del Fuego. Colección Poblamiento Humano. Universidad de Magallanes, Punta Arenas.

Christensen M., Legoupil. D., 2016. Tecnología ósea en Patagonia austral: la cadena operativa del trabajo sobre huesos de guanaco en el sitio Offing 2 (Estrecho de Magallanes). Arqueología de la Patagonia, de mar a mar. CIEP, Rio Negro, pp. 155-165.

Christidou, Rozalia, Legrand, Alexandra, 2005. Hide working and bone tools: experimentation design and applications. Hooves to Horns, from Mollusc to Mammoth. Manufacture and Use of Bone Artefacts from Prehistoric Times to the Present: proceeding of the 4th Meeting of the ICAZ Worked Bone Research Group, at Tallinn, 2631 of August 2003. Tallinn Book Printers Ltd, pp. 385-396.

Clemente Conte, I., Moreno Rudolph, F., López Mazz, J., Cabrera Pérez, L., 2010. Manufactura y uso de instrumentos en hueso en sitios prehistóricos del este de Uruguay. Revista Atlántica-Mediterránea de Prehistoria y Arqueología Social 12, 75-93.

d́Errico, F., Backwell, L., Wadley, L., 2012. Identifying regional variability in Middle Stone Age bone technology: the case of Sibudu Cave. J. Archaeol. Sci. 39, 2479-2495.

Fiore, D., 2011. Art in time. Diachronic rates of change in the decoration of bone artefacts from the Beagle Channel region (Tierra del Fuego, Southern South America). J. Anthropol. Archaeol. 30, 484-501.

Fiore, D., 2012. Diseños y Tempos en el arte mobiliar del Canal Beagle (Tierra del Fuego). Una exploración de los ritmos de cambio En la decoración de artefactos óseos. Relaciones de la Sociedad Argentina de Antropología. 37, 183-206.

Gallardo, C., 1910. Los Onas. Cabaut y Cía, Buenos Aires. 
Gates St-Pierre, C., 2007. Bone Awls of the St. Lawrence Iroquoians: a microwear analysis. In: Gates St-Pierre, C., Walker, R. (Eds.), Bones as Tools: Current Methods and Interpretations in Worked Bone Studies, BAR International Series 1622, pp. 107-118.

Griffitts, J., 1997. Replication and analysis of bone tools. In: Hannus, L., Rossum, L., Winham, R. (Eds.), Proceedings of the 1993 Bone Modification Conference Hot Springs, South Dakota: 236-246. Sioux Falls, Archeology Laboratory, Augustana College.

Gusinde, M., 1982 [1931]. Los indios de Tierra del Fuego. Tomo I: Los Selk'nam. CAEA, Buenos Aires.

Hutson, J., García-Moreno, A., Noack, E., Turner, E., Villaluenga, A., GaudzinskiWindheuser, S., 2018. The Origins of Bone Tool Technologies, RömischGermanisches Zentralmuseum Leibniz-Forschungsinstitut für Archäologie, Germany.

Legrand, A., 2007. Fabrication et utilisation de l'outillage en matières osseuses du Néolithique de Chypre: Khirokitia et Cap Andreas-Kastros. British Archaeological Report, International Series, Oxford, 1678.

Legrand, A., Sidéra, I., 2007. Methods, means, and results when studying European bone industries. In: Gates St-Pierre, C., Walker, R. (Eds.), Bones as Tools: Current Methods and Interpretations in Worked Bone Studies, BAR International Series 1622, pp. 67-79.

LeMoine, G. 1991. Experimental Analysis of the Manufacture and Use of Bone and Antler Tools among the Mackenzie Inuit. Ph. D. Dissertation, University of Calgary, Alberta. MS.

Le Moine, G.M., 1997. Use wear analysis on bone and antler tools of the Mackenzie Inuit. In: International Series $\mathrm{N}^{\circ}$ 679. British Archaeological Reports, Oxford.

LeMoine, G.M., 1994. Use wear on bone and antler tools from the Mackenzie Delta, Northwest Territories. Am. Antiquity 59 (2), 316-334.

Lothrop, S.K., 1928. The Indians of Tierra del Fuego. Museum of the American Indians, New York.

Maigrot, Y., 2003. Etude technologique et fonctionnelle de l'outillage en matières dures animales, la station 4 de Chalain (Néolithique final, Jura, France). Doctoral dissertation, University París 1.

Mallye, J.-B., Thiébaut, C., Mourre, V., Costamagno, S., Claud, E., Weisbecker, P., 2012. The Mousterian bone retouchers of Noisetier Cave: experimentation and identification of marks. J. Archaeol. Sci. 39, 1131-1142.

Morello, F., San Román, M., Prieto, A., 2004. Informe de actividades de sondeo en el sitio Marazzi 2 sector 1 (río Torcido, Tierra del Fuego). Magallania 32, 233-238.

Morello, F., Calás, E., Torres, J., Borella, F., San Román, M., Martin, F., Contreras, L., Martínez, I., Alfonso-Durruty, M., Massone, M., 2015. Punta Baxa 7: Sitio arqueológico de la costa norte de Tierra del Fuego, Estrecho de Magallanes (Chile). Magallania 43-2, 167-188.

Mozota, M., 2012. El hueso como materia prima: El utillaje óseo del final del Musteriense en el sector central del norte de la Península Ibérica. Doctoral dissertation. Facultad de Filosofía y Letras. Universidad de Cantabria, Cantabria.

Mozota, M., 2017. Experimental programmes with retouchers: Where do we stand and where do we go now? In: Hutson, J.M., García-Moreno, A., Turner, E., Villaluenga, A., Gaudzinski-Windheuser, S. (Eds.), The Origins of Bone Tool Technologies. RömischGermanisches Zentralmuseum, Mainz, pp. 1-18.

Müller, P.S., 1776. Des Ritters Carl von Linné, königlich schwedischen Leibarztes sc. Wollständiges Natursystem nach der zwölsten lateinischen Ausgabe und nach Anleitung des holländischen houttuynischen Werks mit einer ausführlichen Erklärung. Suppl. und Registerband. Nürnberg. 342-344.

Muñoz, A.S., 2002. La explotación de Mamíferos por cazadores-recolectores terrestres de Tierra del Fuego. Fac. de Filosofía y Letras. UBA.

Muñoz, S.A., 2012. Guanaco Butchering by Hunter-gatherers from Isla Grande de Tierra del Fuego, Southern Patagonia. Bones for tools - tools for bones The interplay between objects and objectives. McDonald Institute for Archaeological Research, Monographs, Cambridge, pp. 75-86.

Nami, H. G., Scheinsohn, V., 1997. Use wear Patterns of Bone experimental Flakers: A preliminary report. In: Hannus, L.A., Rossum, L., Winham, R.P. (Eds.), Proceedings of the 1993. Bone Modification Conference, Occasional Publication $\mathrm{N}^{\circ} 1$. Hot Springs, South Dakota, pp. 256-264.

Salemme, M., Bas, M., Bártoli, V. y Santiago, F., 2019. La arqueofauna del sitio Margen Sur, Río Grande, Tierra del Fuego (Argentina). Cuadernos del Instituto Nacional de Antropología y Pensamiento Latinoamericano. 7: 232-244.

Santiago, F., 2013. La ocupación humana en el norte de Tierra del Fuego durante el Holoceno medio y tardío. Editora Cultural Tierra del Fuego, Ushuaia.

Santiago, F., Pal, N., Salemme, M., 2019a. Tecnología ósea en el Holoceno tardío de Tierra del Fuego (Argentina): el sitio Las Vueltas 1. Archaeofauna, 28. In press.

Santiago, F., Pal, N., Salemme, M., Bartoli, V., Lasa, A., 2019b. Use and forget: Contribution to the discussion about the bone tools called "machacadores" (pounders), Patagonia, South America. J. Archaeolog. Sci.: Rep. 28, 102012.

Santiago, F., Vázquez, M., 2012. Dietas promediadas: explorando el registro zooarqueológico supra-regional en Tierra del Fuego. Revista del Museo de Antropología. 5: 225-238.

Scheinsohn, V.G., Ferretti, J.L., 1995. Mechanical properties of bone materials as related to design and function of prehistoric tools from Tierra del Fuego (Argentina). J. Archeol. Sci. 22: 711-717.

Scheinsohn, Vivian, 1993/1994. Hacia un modelo del aprovechamiento de las materias primas óseas en la isla Grande de Tierra del Fuego (Argentina). Relaciones de la Sociedad Argentina de Antropología XIX, 307-324.

Scheinsohn, V., 2010. Hearth and bones: Bone raw material exploitation in Tierra del Fuego. Archaeopress, Oxford.

Scheinsohn, V., 2013. Bone Material and Design Choices in Southern Patagonia. In: Choyke, A., ÓConnor, S. (Eds.). An Offprint from. From these bare bones, Raw materials and the study of worked osseous objects. Oxbow Books, England, pp. 50-58. Semenov, S.A., 1964. Prehistoric Technology. Adams and Mackay, London.

Tejero, J.M., 2009. Hueso, asta y marfil. Tecnología de la explotación de las materias óseas en Prehistoria. Societat Catalana d'Arqueologia, Barcelona. 